\title{
Women's Movement in India: Trajectory of Organization, Ideology and Strategy
}

\author{
Dr. K. Vijaya \\ Associate Professor \& Head \\ Department of Historical Studies \\ Quaid-E-Millath Government College for Women (Autonomous) \\ Chennai, Tamil Nadu, India
}

\begin{abstract}
Indian society started to respond to the characteristic challenges of West, which gradually commenced from the dawn of $19^{\text {th }}$ century. In this context, social reform became the first popular issue among Indian intellectuals who, inspired by the liberal views of social change and in the hope of preventing social abuses and launched movements more particularly for women. It is essential to understand in detail the new women movements, which are manifestations of pluralistic paradigm of development and democracy. Moreover, an insight into the struggle for women's rights will certainly become more intense in the coming decades. There is a qualitative difference and strategic variations between the present women's struggle and earlier liberation movements against oppression. This article focuses on women's movement and its role in India with special focus on Tamil Nadu. It also reviews the nature and working of women's organizations, as a lens to the Indian women's movement.
\end{abstract}

Keywords: Women's Movement, Paradigm, Strategy.

\section{Genesis of Women Organizations}

Movements of reform against the social evils began in India in the early $19^{\text {th }}$ century. They have usually been attributed to external factors, which are due to the impact of western education, missionary activities and promotion of nuclear and monogamous family and liberal ideas of the west. The British and Indian reformers in the $19^{\text {th }}$ century and early part of $20^{\text {th }}$ century have addressed several issues pertaining to women. Most important of them were the campaigns against sati, polygamy and child marriage and agitation in favour of widow remarriage and education for women. It is in the late $19^{\text {th }}$ century, a new spirit had characterized a new social reform movement and issue of women's status had become entangled with intra elite competition in Madras and Bombay presidencies. The early reformers like Raja Ram Mohan Roy and Eshwara Chandra Vidhyasagar were 
actuated mainly by the philanthropic motive and their objective was to bring certain individuals who were suffering under social laws through the awakening of natural consciousness, wherein a strong motive of national efficiency came into play. It is realized that the disabilities of individuals do not affect them alone, but their influence penetrates much farther and weakened and undermined the social fabric. At this juncture, M.G Ranade, an eminent leader of moderate faction, (influenced by the Malabari's proposal of National Association for Social Reform) wanted to form an organization of All - India, base to give a definite shape to the Social Reform movement.

In the early 1880 s the social reformers of Madras, inspired by political leaders, tried to have a closer contact with likeminded people in other parts of South India (1). The new urge was activated when a political conference of that kind was held in Madras during 1884. Accordingly, a South Indian Conference was convened as Hindu Women's Remarriage Association on $31^{\text {st }}$ December 1884 . However, the participation was restricted to graduates presumably with a view to enlist the support of the educated young men in the cause of social reform(2). The Indian National Congress inspired the reformers like Ragunathan Rao and M.G Ranade who wished to discuss the social issues at the congress. It is significant to note that when the leaders of Indian National Congress decided to eliminate the social issues from their agenda in 1886 at Calcutta session, M.G Ranade and Ragunatha Rao formed the National Social Conference (NSC) in 1887 in Madras to provide an All - India forum for discussion of social reforms (3). The National social conferences induced the spirit of nationalizing the social problems and paved the way for the birth of many social reform organizations all over India, though of regional nature, particularly in Tamil Nadu.

During this period, the Bharath Dharma Maha Mandali was founded in 1890 in Punjab by Pandit Deen Dayal Sharma to counter the teachings of Arya Samaj. In 1895, the Sanadhan Dharma Sabha was founded in Haridwar, the Dharma Maha Parishad in South India and Dharma Mahamandali in Bengal to defend orthodox Hinduism. In 1902 these various bodies were united under a single organization called Bharath Dharma Mahamandali, with its headquarters at Varanasi (4). This organization highly affected the status of women since it insisted on the orthodox customs of Hindus, which was unfavourable to the emerging pattern of liberalized atmosphere for women. During the same period, two reform associations functioned in Madras. In 1892, the Madras Hindu Social Reform Association was founded by Viresalingam Pantulu, whose efforts were mainly concerned with the plight of widows. This Association fought for the liberation of women from traditional Hindu customs which degraded women (5). Simultaneously R. Venkat Ratnam Naidu started Social Purity Movement advocating temperance and combating the Devadasi customs. A similar organization, the Madras Hindu Association was founded by Mrs. Annie Besant in 1904, to promote Hindu social and religious 
customs on national lines with the spirit of Hindu civilization. The Seva Sadan was another social reform and humanitarian organization founded in 1885 by the famous Parsi social reformer Behramji M. Malabari, relentlessly fought throughout his life against child marriage and 'enforced widowhood' (6). This organization had branches all over India specialised in the care of socially discarded and exploited women of all castes, providing education, welfare and medical services. Hence, a variety of social reform movements throughout India and Tamil Nadu in particular, devoted to the cause of elevation of position of women and infused new ideas in the minds of people with great enthusiasm, which subsequently resulted in the emergence of new women's groups in Tamil Nadu. In the beginning of $20^{\text {th }}$ century, the progress of western education and growth of national consciousness and social awakening developed a new climate in favour of women in Madras Presidency. The new womanhood, which emerged during this period reflected in women's participation in the National Movement, who also played an important role in the great social and political transformation.

In Tamil Nadu, the scope and structure of women's movement is as diverse as their activities, but they strive to achieve a common goal on the upliftment and development of women, despite their efforts through education, research and training programmes or through counseling, awareness generation activities and a wide range of their services and programmes. In terms of coverage, their activities range from the grass - root level to national level. They also differ as activist groups, policy making bodies, research organizations and professionals Associations. Their target groups may vary from rural to urban women, housewives to working women, illiterates to urban educated middle class women and from selfemployed poor women to highly placed women entrepreneurs.

Although, different categorization of these women's organizations are possible based on their size, coverage, activities and methodology, they have been broadly grouped as follows:

$>$ Social Reform oriented organizations

$>$ Social work-oriented organizations

$>$ Government / Political party-oriented organizations

$>$ Professional women's organizations

$>$ Groups involved in research and documentation of women's issues

$>$ Non-Governmental organizations

\section{Social Reform Oriented Organizations}

The organizations, which are highly social reform orientation aimed at reforming the society by involving themselves in social activities for the rehabilitation of women besides, creating awareness on their fundamental rights and responsibilities. 
Few such organizations in Tamil Nadu were Women Indian Association (WIA), All India's Women Conference (AIWC), Joint Action Council for Women (JACW), Kaingkarya, Forum for Women's Rights and Development (FORWORD), Centre for Women's Development and Research organization, Women's Collective, etc. The credit of establishing the first women organization of all India character goes to Irish Lady Dorothy Jeenarajadasa and Margaret cousins along with Annie Besant, who laid the foundation for Women's Indian Association on $8^{\text {th }}$ May 1917 at Madras (7). This was the first organization in India to make a demand for women's franchise and succeeded in its mission. The official journal of this association "Shri Dharma" carried authentic news of the progress of Indian women's movement in India and around the world. It is important to note that, since its foundation in 1917, Women Indian Association (WIA) played a significant role in the emancipation of women. The WIA adopted a strategy of organizing campaigns to raise their voice against inequality, patriarchal supremacy and non-egalitarian social structure. Furthermore, it organized camps like orientation, training, legal awareness and environmental awareness in order to orient women in all fields pertaining to literacy programmes, wherein the organizations succeeded by conducting total literacy campaign, tuition centres, adult education-Jana Siksha Nilayam and Non-Formal education programmes. It expressed satisfaction on the passing of Child Marriage Restraint Act and Sarada Act against child marriage. Besides, these it emphasized the introduction of compulsory primary education for girls and was responsible for the abolition of devadasi system and suppression of immoral traffic in women (8).

The WIA became the parent of All India Women's Conference (AIWC), which was organized in 1927. It was founded as an educational conference, but from its first session, it focused on both social and educational aspects. In the post independence period, the UNO gave the All India Women Conference (AIWC) a consultative status to ascertain the Indian opinion on worldwide women's issues. Its main objective was to work for society based on the principles of social justice, integrity, equal rights and opportunities for all. It played an active role in initiating and campaigning for the social legislation such as Sarada Act (1929), Special Marriage Act (1954), Hindu Marriage and Divorce Act (1955), Hindu Minorities and Guardianship Act (1956), Suppression of Immoral Traffic among Women and Girls Act (1956), Dowry Prohibition Act (1961), etc. (9). With the passage of time, AIWC has diversified its activities and programmes, which included projects for eradication of illiteracy, family planning, child welfare, vocational training for women, free legal-aid to women in distress and other socio-economic measures. It aims at the upliftment of under privileged sections of society.

The Joint Action Council for Women (JACW) came into existence to support, uphold and protect the interests, status and dignity of women. A politically non-aligned, non-sectarian feminist association, it was formed as a spontaneous response to a call for combined action by women activists and groups. Also, to 
establish and act as a forum, wherein different women's organizations could send their representatives, to coordinate activities concerning women, the idea of a common platform for women's organizations. This was conceived at a workshop held in March 1982, arranged by the United States Information Centre in Madras along with the Madras Branch of the International Zonta Club for Women under the chairmanship of well-known activist and writer Veena Mazuumdar of Delhi and was named as Joint Action Council for Women. Initially, around 30 Women Organizations from Tamil Nadu has participated in the workshop. It was formally registered on July 14, 1983, functioning until then as an ad-hoc committee. It is working towards securing just rights and equal opportunities for women, a centre for counselling women in distress and in need of assistance and striving for the economic and social development of women through various projects (10). During 1983-1990 JACW established six Sahodari centres of which two were in Chennai at YWCA and Andhra Mahila Sabha and one each at Tirunelveli, Salem, Ooty and Kumbakonam respectively. The Aashraya Integrated Shelter project was established in 1985 as a short stay home or crisis centre for women, at the premises of a welfare organization, Andhra Mahila Sabha (11).

The Kaingkarya (meaning noble deed in Sanskrit) was the brainchild of Kaveri Natarajan, a service-minded teacher and came into limelight in 1991 with a view to serve the two most vulnerable sections of society-women and children. Kaingkarya primarily works with the needy at Thirusoolam, Chennai. The organization's maiden initiative 'Project Vazhikatti: empowerment through education' was launched in 1992 (12). It conducted an AIDS awareness programme, with domestic help for marginalized sections as the primary target. The Forum for Women's Rights and Development, (FORWORD) came into existence in 1992 to help battered and deprived women who live emotionally, socially, educationally and most importantly, economically insecure lives. The fundamental motto of it is to reach the oppressed women primarily through awareness and education programmes (13). Apart from counseling programmes and advocacy, regular seminars and workshops on domestic violence are conducted.

The Centre for Women's Development and Research organization was started in 1993 as a platform to help and redress the problems of poor women. The organization's initiatives through 'Manushi' and 'Snehidhi' revolve around female domestic workers and adolescent girls living in slums (14). The programmes offer counseling, leadership training and awareness of gender issues, education and training in life skills. The women's collective is the outcome of collective efforts of six organizations in Tamil Nadu headed by women. The Women's Collective is facilitated by Ms.Sheela through Tamil Nadu Resource Team and was started way back in 1994. Women's Collective organizes people at village level into small selfhelp groups with an average membership of 12 and functions as SHGs helping the members to deal with their personal, family and community issues (15). 
These aforementioned organizations are highly oriented towards social reformation of the society by involving themselves in social activities for rehabilitation of women, besides creating awareness of their fundamental rights and responsibilities. In this category, these organizations have contributed for improving socio-economic conditions of women on one hand and on the other into the overall task of bringing rural development. This is evident from the fact that the activities were invariably oriented towards social welfare programmes.

\section{Overview of Social Work Oriented Organizations}

The second category propagates for betterment of women working over wider areas where women are accessed to involve actively in the programme of action. The social work-oriented organizations aim at catalyzing the women towards development approach to build new models focusing with new programmes and represent needs and aspirations of women. There are nearly 120 social work women organizations in Tamil Nadu among which special mention have to be made about Andhra Mahila Sabha (AMS), Young Women's Christian Association (YWCA), Family Planning Association of India (FPA), Women's Voluntary Service of Tamil Nadu (WVS), Pennurimai Iyakkam (PI), Centre for Development and Women's Studies (CEDAW), Feminist Association for Social Action (FASA), International Foundation for Crime Prevention and Victim Care (PCVC), etc.

\section{Andhra Mahila Sabha (AMS)}

Andhra Mahila Sabha (AMS) is an institution dedicated towards working for the empowerment of women. In 1938 Durgabai Deshmukh started the Andhra Mahila Sabha. The vision of this organization is "Empowering Women" and the motto is to promote the education of women, to propagate traditional values, to uphold the dignity of women, to empower them and to train women to be efficient workers and also to harness their services in building up the future of the nation in general and women in particular (16).

\section{Young Women's Christian Association (YWCA)}

Young Women's Christian Association (YWCA) movement founded in England owes its origin to two different groups. The first group in Madras was founded in 1884, eight years before it was actually called the Young Women Christian Association. This group called the Madras Christian Women's Association was organized shortly after a missionary conference in Calcutta (now Kolkata) in1890 (17). The present YWCA was established in 1892 by the effort of Emily Kinnaird at Madras (now Chennai) in which Sahodari project has been instituted, wherein distressed women were given counseling or legal aid. The YWCA played a remarkable role through the activities of Sahodari and its main aim was to give 
women food and shelter and to offer them vocational training (18). They dedicated Navajeevan project to the care of mentally ill women, providing them occupational rehabilitative therapy. Other projects like community college, Old age home, Nursery and balwadi, rural development project aims to develop and empower women. The YWCA with its motto "By love serve one another" endeavours to promote the full development of women irrespective of their religion or creed (19).

\section{Family Planning Association of India (FPA)}

Family Planning Association of India (FPA) was established in 1949, which broadly work towards creating awareness among people on sexual and reproductive health, family planning and HIV/AIDS. It endeavours to promote sexual and reproductive health, especially among the marginalized sections of society (20).

\section{Women's Voluntary Service of Tamil Nadu (WVS)}

Women's Voluntary Service of Tamil Nadu (WVS) is a voluntary, non-profit, nonsectarian organization established in May 1972 at Raj Bhavan, Madras with a view to bring all women social workers under one forum and organize measures for amelioration the living conditions especially of the weaker and under privileged sections of the society (21).

\section{Pennurimai Iyakkam (PI)}

Pennurimai Iyakkam (PI) was established in 1979, which aims at organizing campaigns and meetings to mobilize poor women in providing support and shelter (22). They take up issues such as violence in marriage and dowry harassment and take on to the streets to infuse thought and bring to the fore problems that warrant immediate attention. The Pennurimai Iyakkam uses techniques like street plays, skits on burning issues, feminist song, posters, exhibitions etc. It is publishing a journal by name 'Pennurimai Kural' (Voice of Women's Right) to implement the ideologies.

\section{Centre for Development and Women's Studies (CEDAW)}

Centre for Development and Women's Studies (CEDAW) was established in Chennai in 1988 (23), which is highly identical with 'Pennurimai Iyakkam'. This is a positive women's network in raising consciousness, general issues affecting women and fighting the stigma associated with HIV/AIDS are the areas of concern for CEDAW. Also, it believed in conducting demonstrations and rallies, which are yet another medium of expressing dissent and calling for a thorough transformation. 


\section{Feminist Association for Social Action (FASA)}

Feminist Association for Social Action (FASA) has started in Chennai, which led the way in dissemination of information on sexual harassment, domestic violence and broke new grounds through its relentless pursuit for laws to counter gender discrimination (24). FASA's primary objective was to counter different forms of gender discrimination and spread awareness on gender issues.

\section{International Foundation for Crime Prevention and Victim Care (PCVC)}

International Foundation for Crime Prevention and Victim Care (PCVC) was instituted in the year 2001 at Chennai with the sole aim of countering domestic violence and providing a range of services for victims. The PCVC's initiatives and services fall under broad categories - crisis intervention and prevention. They include the following: Shanthi - crisis intervention centre for domestic violence victims, Astitva - emergency shelter for women and children, Udhayam community support unit working in tandem with all-women police stations, Vidiyal - project for burn survivors of domestic violence (25).

Thus, the social reform-oriented organizations believe in fighting against all forms of sexual oppression and believe in transcending the existing social order. These organizations are identical in views, which expressed the need to look more deeply into the issues of gender identity i.e., the subordination and oppression of women in the family with special focus on dowry murders, sexual exploitation and women's role in the decision-making process in the family, etc. In this process, they insist on self reliance in order to elevate the economic status of women through equal employment opportunities in both organized and unorganized sectors.

\section{Government / Political Party Organizations}

They are formed to identify, recruit, train, endorse and support women seeking public office. These organizations help women candidates run successful campaigns, hold workshops and developing a platform in motivating volunteers. The social welfare department of the government directs its attention to the implementation of welfare programmes for women. While on one hand the government aided voluntary organizations, conduct many programmes and execute various measures to promote the cause of women, on the other, the political partyoriented women's wings act as catalyst not only to enhance women's interest in politics but also to seek their support for membership in the party.

The Tamil Nadu Social Welfare Board which was constituted in 1954 has been working for the upliftment of people living below poverty line through voluntary institutions in the State with the assistance of Central Social Welfare Board. 
Women's Welfare Department was established by Government of Tamil Nadu in 1947 (26). It provides support to Voluntary Organizations through a variety of programmes to facilitate the empowerment of women through education, training, collective mobilization, awareness creation and also through income generating activities and provision of support services. Also, with the help of funds received from Central Social Welfare Board, the Tamil Nadu Social Welfare Board assists voluntary organizations on a large scale, which serves children, women and handicapped and implements welfare schemes (27).

During the post Independence era, women are increasingly taking interest in political issues and activities. There is a greater awareness among women on the power and right of franchise given to them. Hence, the political parties of Tamil Nadu such as Dravida Munnetra Kazhagam (DMK), All India Anna Dravida Munnetra Kazhagam (AIADMK), Congress (Indira), Communist Party of India CPI (Marxist), Marumalarchi Dravida Munnetra Kazhagam (MDMK), Paataali Makkal Katchi (PMK) and Desia Murpokku Dravida Munnetra Kazhagam (DMDMK) constituted their women's wing with a view to executing their ideology and also to enhance the women membership of their parties.

The Indian National Congress (I) party had firmly entrenched itself in the politics of the nation and of state for more than 50 years. The Mahila Congress or Women's wing of this party was constituted soon after its foundation in 1885 (28). There were a lot of women freedom fighters who took active role in the activities of the party. Next to Congress (I) party, the most dominant party in the political scene of Tamil Nadu is the DMK (an offshoot of Justice Party and Dravidar Kazhagam), which constituted its women's forum in the name of 'Magalir Mandram' on 21.8.1956 (29). The social and cultural ideologies of EV Ramasamy better known as Periyar and his self-respect movement influenced the members of the women's wing of this party.

The ideologies of Karl Marx laid the foundation for the Communist Party, which was split into two and off-shoot was called as CPI (M) in 1964. The party played a vital role in the emancipation of women resulting in the formation of All India Democratic Women's Association (AIDWA) referred to as Jananayaga Madhar Sangam, which was officiated on 09.12.1973 (30). AIDWA works to mobilize women across levels, from the remotest districts to the urban heartland, which believed in the demonstrations, which are most potent method of effecting change. The members take to the streets in large numbers protesting against discriminatory measures or laws, domestic violence, dowry harassment and other issues concerning women. AIDWA's legal aid centre first attempts to find solution to women's problems by counseling parties involved in the dispute and effect reconciliation (31). 
AIADMK was formed in the year 1972 and constituted its women's wing in the same year (32). Though the party ascertains some moderate approach for the women's problem, it did not have any basic character in the mobilization of women in the field of politics. Besides the above mentioned major political parties, the other developing parties in Tamil Nadu are Pattali Makkal Katchi (PMK) founded by Dr. Ramadoss in 1989, Marumalarchi Dravidaa Munnetra Kazhagam (MDMK), which splited from DMK under the leadership of V.Gopalasamy, Desiya Murpokku Dravida Munnetra Kazhagam (DMDMK) (Formed in September 2005) by Vijayakanth also formed their women's wing to gain popularity among women and also to support the women activist groups.

Women's fronts of various political parties focused on their activities towards electoral victory. It is during the International Women's Decade, all political parties in Tamil Nadu have shown greater interest in women's problems. In order to promote and enhance the interests of women and to increase their representation in politics, they instigated their women's wing. The political parties in Tamil Nadu are by and large reluctant to place women in higher positions. Most of these women's wings were created with an ulterior motive only to gain support and popularity among women. However, the ideologies of different Women Movements and Government political party-oriented organizations revealed the fact that they, no doubt, display on the streets for highlighting women's oppression. There is a lot of unevenness in the extent of the activities, programmes, strength of leadership, societal response, level of consciousness etc., in various parts of the state because of the varied cultural differences.

\section{Groups Involved in Research and Documentation of Women's Issues}

The recently emerging women' organizations involve themselves in research and documentation of women's issues. They have attempted to resolve issues of cultural - traditional - patriarchal origin, which has given women a subordinate status in society. They are involved in diverse activities ranging from activism to research and documentation and claim to subscribe to certain ideals such as equity, conservation, gender sensitivity and other related issues. Initiatives: Women in Development (IWID) and Tamil Nadu Social Watch (TNSW) are the two important examples for this category.

IWID is an initiative formed in 1989 by a group of women activists from different regions of India who work to promote the development of women and marginalized with in NGOs in larger society. The key focus of IWID is to collect, compile, critically analyze and disseminate issue based information gathered from widest possible range of materials, including periodicals, unpublished and published articles, reports, papers, books, films, posters, and other documents produced by 
different groups at the state, national and international levels on a variety of topics related to Gender and Development(33).

\section{Tamil Nadu Social Watch (TNSW)}

Tamil Nadu Social Watch (TNSW) came into existence to share a common platform with the aim of materializing aspirations of the people, more particularly women in the state. It is actively engaged in monitoring the performances of the institutions of governance in the state. TNSW through its research and advocacy creates an enabling environment for citizens and the government to identify the hindrances and remove the same so that the latter meets the expectations of the former (34).

\section{Professional Women's Organizations}

The organizations which identify promotional strategies for the protection of women through concrete efforts are referred to as professional women's organizations. They aim to eradicate poverty of women and also increase their economic position integrating them in all sectors of social and economic policy. The following are some of the organizations working with the above objective:

\section{Working Women's Forum (WWF)}

Working Women's Forum (WWF) was started in 1978 as a responsive organization, working for the rights of poor women and facilitating access to credit, education, healthcare and other fundamental services. It works with 14 branches in urban, semi-urban and rural areas across Tamil Nadu, Andhra Pradesh and Karnataka. WWF is essentially a movement of grass root women, an initiative covering poor rural and urban working-class women in three Southern States. WWF has promoted two subsidiary institutions to work towards empowering poor women: The Indian Cooperative Network for Women (ICNW) and The National Union of Working Women. WWF's pioneering initiatives is micro insurance. Social security coverage for members is provided through tie-ups with the Life Insurance Corporation of India (LIC) and Royal Sundaram Alliance Pvt. Limited (RSA). Women are covered under life, accident, disability and health through the ICNW (35).

\section{Marketing Organization of Women Entrepreneurs (MOOWES)}

Marketing Organization of Women Entrepreneurs (MOOWES) is a pioneer in assisting women entrepreneur's market products was the brainchild of Seetha Ranganathan and Janaki Ananth. It came into being in 1990 with initial assistance from Indian Bank. MOOWES in Chennai works to encourage women to set up their own manufacturing units or trade in products of their choice. MOOWES offers its 
members a platform to reach consumers primarily through participations in exhibitions or by conducting exhibition-cum-sale. The women receive training in jute making, food processing, tailoring and leather technology to name a few. In addition, MOOWES' annual feature 'Shakthi', an exposition comprising seminars, workshops and exhibition, which is the largest stage for members to showcase their products as well as learn new skills (36).

\section{FICCI Ladies Organization (FLO)}

FICCI Ladies Organization (FLO) is an organization instituted under Federation of Indian Chambers of Commerce and Industry (FICCI). FLO is providing a platform for women to express their concerns and an opportunity to excel in their chosen business endeavours with its headquarters in Delhi. The Chennai Chapter, the first regional Chapter of FLO was set up in 1996 with 'power to empower' as their mission. The FLO chapters in Coimbatore, Hyderabad, Jaipur, Kolkata and Mumbai serve as nodal centres and reach out to other areas of the country. FLO is determined to create a space to promote entrepreneurship and business acumen among women professionals. This is the only national-level trade organization, which serves as a forum for women to interact and share ideas and experiences (37).

\section{Association for Non-Traditional Employment of Women (ANEW)}

Association for Non-Traditional Employment of Women (ANEW) started in 1997, provides free training for young women from underprivileged families and helps them to get access to practical job skills and self-sustaining employment. ANEW's projects can be divided into five broad categories: Housekeeping, Diploma in Computer Applications, Car driving, Autorickshaw driving, Home nursing. In addition to this, they also offer counseling and self awareness classes for personality development (38).

\section{Centre for Entrepreneurship Development (CED)}

Centre for Entrepreneurship Development (CED) has undertaken a number of skilled training and entrepreneurship development activities for the benefits of women in 2001 at Madurai. They conducted a number of workshops / seminars / conferences at regional and national level on Women Empowerment in association with other developmental agencies with the support of Government agencies. CED has imparted Skilled Training to around 300 Self Help Group women in and around Madurai District on candle making, food processing - pickle and juice making, cleaning powder manufacturing, etc. (39). 


\section{Women's Entrepreneurship Promotional Association (WEPA)}

Women's Entrepreneurship Promotional Association (WEPA) was set up in 2001, which empowers women through training, imparting information on health and hygiene, vocational training, exposure through seminars and workshops, exhibitions and guidance and consultancy services. Although, WEPA is not part of the SHG movement, it provides vocational training to members of SHGs run by other non-governmental organizations. It networks with individuals and organizations to set up units for women entrepreneurs (40).

\section{Suggestions}

To achieve gender parity the women organizations should periodically inculcate the following aspects:

$>$ Should motivate women to mobilize all resources from the grass root level to the national level to maximize their impact of their programmes.

$>$ Mobilize public opinion and strengthen the social efforts against oppressive institutions and age-old beliefs.

$>$ Work to transform existing gender discriminatory laws and procedures.

$>$ Transform the power relations in the family and other social institutions.

$>$ Can help bring about more equitable gender relations within the family and society.

$>$ Engage women at all levels to eradicate poverty, promote peace and achieve sustainable development proponents of their rights, healthy partnership between men and women.

\section{Conclusion}

As A. R. Desai has observed, "Indian women are developing a new sensitivity and consciousness which will no longer tolerate the suffocating financial, institutional, political and cultural norms which place them in a humiliating subject status". Women's movements in Tamil Nadu during $20^{\text {th }}$ century played a vital role in mobilizing the mass for women's rights. It is from the aforesaid conceptual review; one can understand that social reform-oriented organizations mobilize the mass for women's right against innumerable forms of women's oppression. They involved in social activities, organizing campaigns against inequality, patriarchical supremacy and unequal social structure. The social work-oriented organizations focus on issues like discrimination, harassment, economic inequality, etc. They organize protest rallies, street plays, awareness meetings, legal assistance, self-employment training for underprivileged women. The government/political party-oriented organizations act as catalyst not only to enhance women's interest in politics but also to work for the political empowerment of women. The groups involved in research and 
documentation of women's issues attempt to resolve issues of cultural traditionalpatriarchal origin, which has given women a subordinate status in society. The professional women's organizations are aiming to eradicate poverty of women and also increase their economic position by integrating them in all sectors of social and economic policy. Hence, women must develop the attributes of initiation, persistence and tenacity to deal with the local bureaucracy and mobilize other women. The government should frame comprehensive Gender Policy at the State and National level outlining the government's commitment to achieve gender equality and gender justice. The organizations need to move away from the notion of women's development as a component and congregate on women's development as a process to achieve and attain 'empowerment'. A qualitative difference and strategic variations is required between the present women's struggle and earlier liberation movements against oppression to bring in Women Empowerment at large.

\section{References}

Indian Social Reformer, Vol.XXIII, pp.209-210.

R.Ragunatharao, (1887), A lecture on the Marriage of the Hindoos, Indore, p5.

Report of the Second National Social Conference, Allahabad, p54.

Report of the Second National Social Conference, Allahabad, p55.

Address Delivered by G. Subramania Iyer at the Fifth Anniversary meeting of the Madras Hindu Social Reform Association, 1987.

Gopalakrishnan (1981), Political Movements in South India, Madras, p16.

First Annual Report of the Women Indian Association (WIA), 1917.

Women Indian Association, Golden Jubilee Celebration Souvenir, 1917-1965.

Annual Reports of the All India Women's Conference (AIWC), 1950-1965.

Third Annual Report of the JACW, 1986.

Report of the Andhra Mahila Sabha, 1985.

Annual Report of the Kaingkarya, 2002-2003.

Report of the FORWARD, 2003. 
Brochure, Centre for Women's Development and Research organization

Report of the Women's Collective, 2011.

Annual Report of the Andhra Mahila Sabha, 2009-2010.

Gladys Ambat (1992), More Grasps to Reach: A Hundred Years of the Madras Y.W.C.A, Young Women's Christian Association, Madras.

Sahodari Network Project, A Project of the Joint Action Council for Women, 1992.

Annual Report of the YWCA of Madras 2010-2011.

Report of the Family Planning Association of India (FPA), 2010.

Annual Report of the Women's Voluntary Service of Tamil Nadu, 1990.

Annual Report of the Pennurimai Iyakkam, 1981.

Verbatim - A Journal of Centre for Development of Women Studies.

Report of the Feminist Association for Social Action (FASA), 2008

Report of the International Foundation for Crime Prevention and Victim Care (PCVC), 2010/ www.pcvconline.org.

Annual Report of the Tamil Nadu State Social Welfare Board, 1989.

Government of Tamil Nadu, Social Welfare and Nutritious Meal Programme Department, Policy note 2010-2011.

Election Manifesto of the Indian National Congress (I) Party, 1985.

T. M Parthasarathy, (1961), History of DMK (Tamil), Madras, p193.

All India Democratic Women's Association-Aims \&objectives- By law.

'Towards the Dawn'-Report of the Democratic Women's Association, 2006

Election Manifesto of AIADMK, 1991.

Report of the IWID, 2010-2011.

Report of the Tamil Nadu Social Watch (TNSW), 2010. 
Holistic Research Perspectives Vol.5

Report of the Working Women's Forum (WWF), 2010.

Brochure, MOOWES.

Report of the FICCI Ladies Organization (FLO), 2002.

Report of the Non-Traditional Employment of Women (ANEW), 2011

Report of the Centre for Entrepreneurship Development, 2009.

Interview with Mrs. Prema Desigan, Secretary, WEPA, on 6.1.2011. 